\title{
PEMBERDAYAAN APARAT PEMERINTAH DESA HUNTULOHULAWA KECAMATAN BONGOMEME DALAM REVITALISASI DATA PROFIL DESA DENGAN OPTIMASI DUKUNGAN MANAJEMEN BERBASIS WEB
}

\section{Empowering Huntulohulawa Village Government Officials in Data Revitalization of Huntulohulawa Village Profile with Web-Based Management Optimization}

\author{
Amirudin Yunus Dako'), Jumiati Ilham ${ }^{2)}$ \\ 1,2 Jurusan Teknik Elektro, Fakultas Teknik Universitas Negeri Gorontalo \\ Email: amirudin.dako@ung.ac.id ${ }^{1)}$
}

\begin{abstract}
ABSTRAK
Kegiatan ini ditujukan untuk melakukan pemberdayaan aparat pemerintah desa Huntulohulawa sebagai mitra desa, dalam revitalisasi data profil desa dengan optimasi dukungan manajemen berbasis web, yang selanjutnya dapat menjadi titik pangkal bagi penyelenggaraan pemerintahan, penentuan kebijakan, penyusunan Rencana Pembangunan Jangka Menengah Desa (RPJMDes), implementasi program pembangunan desa dan hal-hal terkait lainnya yang didukung oleh dokumen resmi yang lengkap dan valid. Pelaksanaan kegiatan dilakukan secara partisipatif bersama masyarakat, aparat pemerintah desa dan lembaga di desa sebagai mitra desa bersama mitra eksternal lainnya, menggunakan metode Participatory Rural Appraisal (PRA) yang dikombinasikan dengan metode penerapan ipteks memanfaatkan aplikasi komputer, metode pembelajaran orang dewasa, learning by doing dan metode lainnya. Penerapan kombinasi metode dilakukan dengan mempertimbangkan aspek gender dan difokuskan pada upaya untuk meningkatkan partisipasi masyarakat dalam setiap pelaksanaan kegiatan. Di akhir program pengabdian, setelah melalui serial pelatihan dan pendampingan, mitra desa telah dapat mengelola website desa yang terakses global berbasis sistem informasi geografis secara berkelanjutan. Website desa memuat keseluruhan produk luaran program pengabdian antara lain peta desa, data kependudukan, profil desa, monografi desa, desa dalam angka, dilengkapi modul surat menyurat otomatis dan papan informasi digital.
\end{abstract}

Kata kunci: pemberdayaan, aparat desa, revitalisasi, profil desa, Desa Huntulohulawa

\begin{abstract}
This activity aim is to empower Huntulohulawa village government officials, i.e., be a village partner, revitalize village profile data, optimize web-based management support. It can be a starting point for good governance, policy-making, preparation of the Village Medium Term Development Plan (RPJMDes). Implementation of village development programs and other related matters supported by complete and valid official documents. The implementation activities are carried out in a participatory manner with the community, village government officials, and village institutions as village partners and other external partners. They were using the Participatory Rural Appraisal (PRA) method combined to applying science and technology, adult learning methods, learning by doing., and other methods. The use of a combination of methods is applying with considering aspects of gender equality and is focused on efforts to increase community participation in every activity implementation.

At the end of the community service program, after going through a series of training and mentoring, the village partners have been able to manage the village website that is accessed globally sustainably based on geographic information systems. The village website contains the entire product of service
\end{abstract}

E-ISSN : 2655-0253 
program outputs, including village maps, population data, village profiles, village monographs, villages in numbers, complete with automatic correspondence modules, and digital information boards

\section{Keywords: empowerment, village officials, revitalization, village profile, Desa Huntulohulawa}

\section{PENDAHULUAN}

Desa Huntulohulawa adalah salah satu desa yang terletak di kecamatan Bongomeme Kabupaten Gorontalo, memiliki penduduk sejumlah 1.044 jiwa, 433 kepala keluarga (KK) terdiri dari 499 laki-laki dan 545 perempuan. Luas desa tercatat sebesar $2.06 \mathrm{~km} 2$, memiliki 2 dusun dan mata pencaharian utama masyarakatnya adalah petani (tabama), selebihnya dalam jumlah relatif sedikit berprofesi sebagai pekerja perkebunan, pertambangan, konstruksi, pegawai negeri sipil dan profesi lainnya(BPS Kabupaten Gorontalo, 2018).

Untuk mendapatkan gambaran lebih jelas terkait kondisi desa, kemudian dilakukan observasi serta wawancara dengan kepala desa dan perangkat desa. Observasi dilakukan untuk melihat kondisi terkini desa sedangkan wawancara ditujukan untuk mendapatkan gambaran proses-proses pengelolaan dan operasional pemerintahan desa.

Hasil observasi dan wawancara dengan kepala desa yang telah dilakukan mendapati bahwa desa ini belum memiliki profil desa yang lengkap sebagaimana diatur dalam Peraturan Menteri Dalam Negeri No. 12 tahun 2007 tentang Pedoman Penyusunan Dan Pendayagunaan Data Profil Desa dan Kelurahan (Pemerintah Indonesia, 2007). Data yang ada hanyalah yang dijumpai dalam papan informasi yang terpampang di kantor desa dengan kualitas yang meragukan dan beberapa diantaranya sudah kadaluarsa. Data lainnya dijumpai pada catatan-catatan kepala desa dan perangkat desa lainnya yang terpisah dan tidak menyatu dalam satu dokumen profil desa yang utuh.

Hasil penelusuran internet mendapati bahwa antara sumber data yang satu dengan lainnya berbeda. Luas wilayah desa misalnya, dokumen kecamatan Bongomeme dalam angka 2017 mencantumkan bahwa luas wilayah desa Huntulohulawa sebesar 2,06 km2, tetapi dalam menu data pokok Desa Huntulohulawa untuk tahun laporan 2017 pada laman web sistem informasi desa dan kelurahan (Kementrian
Dalam Negeri Republik Indonesia, 2018), yang dikelola oleh Kementrian Dalam Negeri RI Dirjen Pemberdayaan Masyarakat dan Desa, luas desa Huntulohulawa tidak ditemukan.

Hal ini selanjutnya diakui oleh kepala desa bahwa beberapa tahun yang lalu ketika desa ini berpisah dengan desa induk, sampai saat ini belum pernah dilakukan pemetaan. Data luas wilayah desa hanya diestimasi besarannya tanpa ada pemetaan ataupun pengukuran wilayah desa secara cermat. Lebih lanjut kepala desa menuturkan bahwa dasar estimasi luas wilayah desa hanya diukur dengan menggunakan pengukur jarak (speedometer) yang ada pada sepeda motor.

Lebih lanjut didapati bahwa data lain terkait tipe, potensi dan perkembangan desa juga bernasib sama, padahal data dimaksud menjadi rujukan dalam penyusunan profil desa disamping data-data pendukung lainnya. Kurangnya data untuk penyusunan profil desa yang detail, valid dan akurat menyulitkan penyelenggara pemerintahan di desa menentukan kebijakan pembangunan desa serta perencanaan desa hanya didasarkan pada data yang berupa estimasi.

Pengakuan kepala desa dan aparatnya dalam wawancara dan observasi awal yang telah dilakukan mendapati bahwa proses penyusunan dokumen profil desa dan dokumen lainnya terkendala oleh beberapa hal:

- minimnya tingkat pengetahuan dan ketrampilan aparatur desa dalam pengolahan dan analisis data dengan bantuan komputer,

- Data desa yang ada terpisah-pisah dan tidak terintegrasi dalam dokumen yang lengkap, dan belum ada aplikasi yang secara khusus didesain untuk mengelola data desa secara sistematis dan terpadu,

- Banyaknya data yang harus digali dan diinput ke dalam profil desa yang membutuhkan tenaga, waktu dan biaya yang tidak sedikit,

- Data tidak bisa dimanfaatkan secara optimal serta software yang ada tidak mendukung untuk memanggil data secara cepat, 
sehingga menghambat proses pelayanan di desa,

- belum ada kegiatan bimbingan maupun pendampingan penyelenggara pemerintahan dalam menyusun profil desa,

- Sistem pengelolaan arsip masih konvensional dan manual sehingga memiliki resiko tinggi dengan gangguan yang akibatkan karena alam (banjir \& kebakaran) dan ganguan hama rayap.

Diskusi lebih lanjut menyepakati bahwa alternatif solusi yang akan ditempuh adalah melakukan pemberdayaan aparat pemerintah desa Huntulohulawa dalam revitalisasi data profil desa dengan optimasi dukungan manajemen berbasis web, melalui serangkaian kegiatan penguatan kapasitas aparat pemerintah desa dengan menerapkan beberapa kombinasi metode untuk mencapai target terukur dan terencana, dikemas dalam bentuk program pengabdian berupa KKN PPM (Kuliah Kerja Nyata Pembelajaran dan Pemberdayaan Masyarakat) yang melibatkan institusi perguruan tinggi yakni Universitas Negeri Gorontalo

\section{METODE PELAKSANAAN}

Lokasi program pengabdian di desa Huntulohulawa Kecamata Bongomeme Kabupaten Gorontalo Provinsi Gorontalo.

Gambaran umum masalah, solusi, penerapan metode dan target/indikator luaran dilukiskan pada gambar 1 .

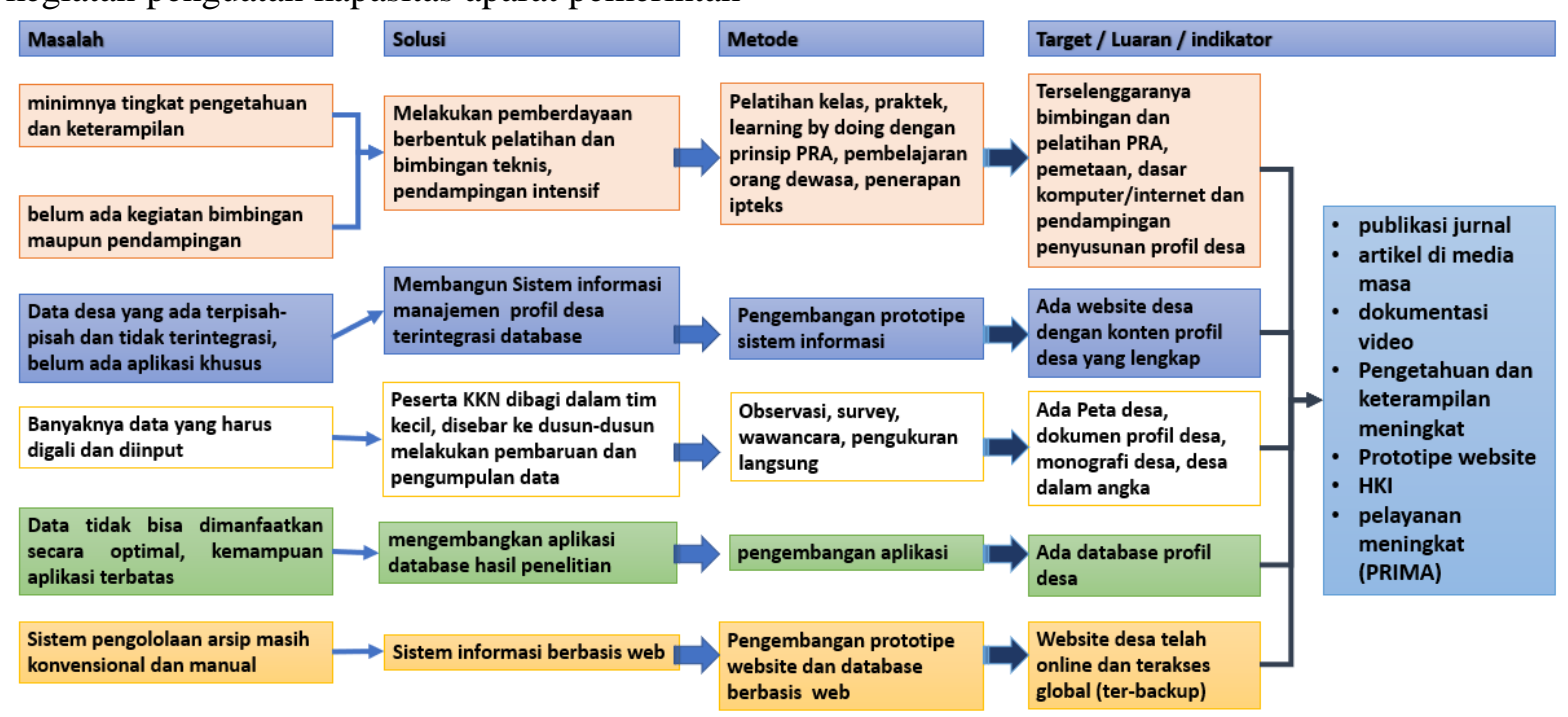

Gambar 1. Gambaran umum masalah, solusi, metode dan target

Alur pelaksanaan program secara grafis dilukiskan pada gambar 2 .

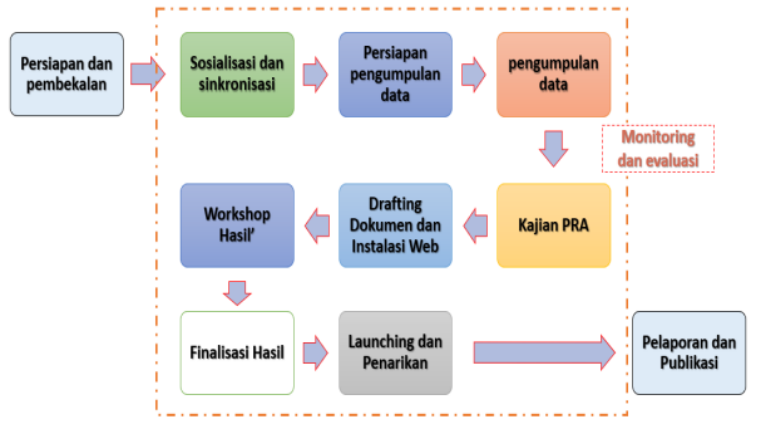

Gambar 2. Alur pelaksanaan program
KKN PPM direncanakan akan melakukan kegiatan terstruktur untuk menjawab permasalahan yang ada, dimulai dari sosialisasi dan sinkronisasi program, analisis kondisi eksisting desa, perumusan rencana kegiatan bersama, penyiapan instrument pengumpulan data, penyiapan kelompok kerja, pelatihanpelatihan, penguatan kapasitas penyelenggara pemerintahan di desa, pelaksanaan pengumpulan data, pengelolaan data serta publikasi data dalam bentuk dokumen profil desa, monografi desa serta sistem informasi berbasis web untuk pengelolaan data desa yang optimal terbantu komputer.

Keseluruhan kegiatan KKN PPM akan dilakukan bersama masyarakat, aparat desa 
termasuk kepala desa, PKK, Dasa wisma, karang taruna sebagai mitra desa bersama mitra lainnya, dengan mempertimbangkan aspek gender dan difokuskan pada upaya untuk meningkatkan partisipasi masyarakat dalam setiap pelaksanaan kegiatan yang bertujuan untuk melakukan pemberdayaan aparat pemerintah desa dalam revitalisasi data profil desa dengan optimasi dukungan manajemen berbasis web, melalui serangkaian kegiatan pembaruan dan pengelolaan data profil desa secara berkelanjutan untuk kemudian disajikan dalam sistem informasi desa berbentuk website sebagai sarana penyampaian informasi yang mudah diakses dan tersedia secara daring.

Adapun gambaran iptek yang akan diterapkan, lebih lanjut diuraikan sesuai indikator ketercapaian target yang direncanakan yakni

- Penerapan aplikasi komputer untuk pemetaan dan sistem informasi geografis (SIG) menggunakan ARCGIS atau aplikasi pemetaan lainnya, teknik survey dan tracking, pemakaian GPS (global positioning system) untuk menghasilkan Peta Desa Huntulohulawa dengan format standar lengkap dengan acuan koordinat lokasi,

- Penerapan aplikasi komputer dasar dalam rumpun Microsoft Office (MS Excell, MS Word, MS powerpoint), aplikasi pengolah foto dan video dalam rumpun Adobe studio (Adobe photoshop, Adobe premiere) untuk menghasilkan

- Dokumen Profil desa yang terdiri atas 3 dokumen utama yakni data dasar keluarga, potensi desa dan tingkat perkembangan,

- dokumen Monografi Desa dan desa Huntulohulawa dalam angka,

- dokumentasi kegiatan dan pelaporan kegiatan

- Penerapan aplikasi pemrograman web untuk menghasilkan Prototipe Sistem informasi terpadu berbasis web untuk sajian informasi data profil desa. Aplikasi dimaksud dapat menggunakan HTML (HyperText Markup Language), PHP (Prehypertext Prepocessor), javascript, Xampp [x (empat sistem operasi apapun), Apache, MySQL, PHP dan Perl], MySQL (My Structured Query Language), CSS (Cascading Style Sheet) maupun tools web lainnya.
- Penerapan aplikasi berbasis komputer dan pemakaian perangkat teknologi informasi lainnya (dasar komputer, optimasi internet, peraga LCD, wifi, dan perangkat nirkabel lainnya) untuk mendukung kegiatan penguatan kapasitas aparat desa dalam kegiatan pelatihan, temu desa, sosialisasi, workshop serta pengelolaan sistem informasi berbasis web secara umum.

Kelompok sasaran program pengabdian ini adalah aparat pemerintah desa beserta lembaga-lembaga yang ada di desa, mulai dari kepala desa, sekretaris desa, kepala urusan (kaur), bendahara sampai kepala dusun dan didukung oleh tim penggerak PKK, LPM, Hansip, BPD Karang Taruna, pengelola Badan badan usaha milik desa (BUMDES) dan lembaga lain yang ada di desa. Untuk memaksimalkan ketercapaian tujuan, program pengabdian ini juga menggaet mitra eksternal yakni organisasi nirlaba (Japesda, n.d.) maupun kelompok studi mahasiswa pecinta alam Alaska yang memiliki kompetensi, kapasitas dan berpengalaman ikut serta dalam memfasilitasi kegiatan dengan tema yang mirip pada tahun sebelumnya.

\section{HASIL DAN PEMBAHASAN}

Uraian hasil dan pembahasan program dituliskan sesuai alur tahapan pada gambar 2 .

\section{Sosialisasi dan Sinkronisasi Program}

Sosialisasi program bertujuan untuk menggali lebih banyak informasi awal kondisi desa, menemukenali potensi, permasalahan, memetakan sumber daya pendukung serta menjelaskan maksud dan tujuan program kepada kelompok sasaran. Sosialisasi program dilakukan dalam bentuk formal pada pertemuan desa dan informal dalam kegiatan kemasyarakatan misalnya hajatan masyarakat atau kegiatan keagamaan yang dikemas dalam bentuk program safari ibadah Jumat maupun secara door to door.

Sinkronisasi ditujukan untuk menyelaraskan alur tahapan program pengabdian dengan agenda kegiatan kelompok sasaran sehingga saling mendukung satu sama lain, dilakukan pada tahapan sosialisasi atau secara non formal melalui diskusi dengan pemerintah desa, dengan mengacu pada 
dokumen rencana pembangunan jangka menengah desa (RPJMDes).

Tahapan ini kemudian menghasilkan gambaran awal permasalahan yang ada di desa, sumber daya yang tersedia, serta prioritas program dan masalah yang harus segera diselesaikan. Hasil dari tahapan ini kemudian didiskusikan di tingkat internal tim KKN PPM dan selanjutnya menghasilkan jadwal dan rencana tindak tim KKN PPM yang memuat mekanisme pelaksanaan program inti yang tersinkronisasi dengan agenda kegiatan pemerintah maupun masyarakat desa, serta rumusan program kegiatan inti bersama dan program tambahan, sebagaimana yang dilukiskan pada gambar 3 dan gambar 4 .

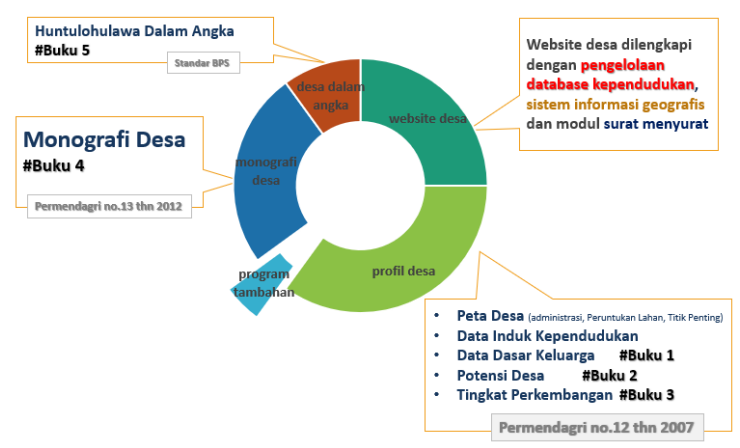

Gambar 3. Program Inti

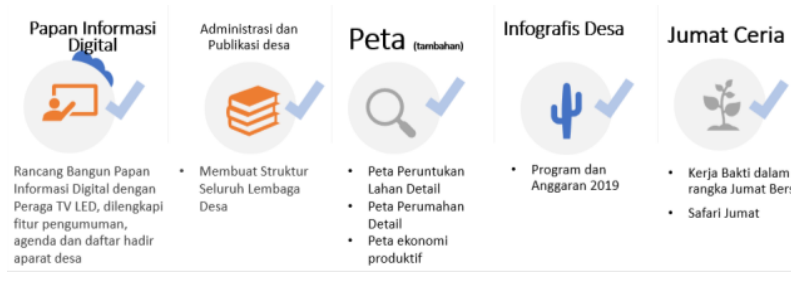

Gambar 4 Program tambahan

\section{Pembuatan Profil Desa}

\section{Persiapan dan Pembekalan Tim}

Persiapan tim dilakukan melalui kegiatan pembekalan, pembentukan tim, penyiapan jadwal serta penyiapan format pengambilan data. Pembekalan dilakukan dengan mengenalkan secara ringkas terkait teknik PRA melalui pelatihan dengan metode non formal dalam kelas bagi mahasiswa dan kelompok sasaran. Selanjutnya tim kemudian dibentuk dan diorganisir sesuai dengan tugas pokok dan fungsi masing-masing, antara lain tim surveyor, tim pemetaan, tim web, tim analis data, tim dokumentasi, tim infografis, tim administrasi/training, dan supporting tim.

\section{Pengambilan Data}

Pengambilan data dilakukan dengan cara mendatangi rumah penduduk untuk diwawancarai menggunakan format pengambilan data yang telah disiapkan bersama dengan kepala dusun dan aparat desa. Data per 29 Juli 2019 mencatat bahwa jumlah rumah yang disurvey tercatat sebanyak 295 rumah, 310 KK dan 1036 jiwa. Pada tahap ini pula dilakukan pengambilan data spasial yang ditujukan untuk memperbaharui kembali sketsa peta desa.

\section{Analisis Data}

Kegiatan ini dilaksanakan oleh tim yang ditunjuk setelah pengambilan data selesai. Data kependuduka yang diperoleh selanjutnya diolah dengan aplikasi MS Excell untuk dianalisis lebih lanjut. Pada tahapan ini, proses seleksi data, klasifikasi, triangulasi serta validasi dan koreksi data dilakukan bersama kepala desa dan aparat desa. Tahapan ini kemudian menghasilkan data dasar bagi penyusunan buku profil, monografi desa serta desa dalam angka pada tahapan berikutnya.

\section{Penyusunan Draft Profil Desa}

Data yang telah diolah sebelumnya selanjutnya disusun menjadi draft dokumen profil desa, monografi desa dan desa Huntulohulawa Dalam Angka dengan merujuk pada (Pemerintah Indonesia, 2007), (Pemerintah Indonesia, 2012) dan standar publikasi kecamatan dalam angka oleh Biro Pusat Statistik.

Proses Penyusunan draft dokumen memakan waktu kurang lebih 1 minggu, dilakukan di posko induk bersama dengan aparat desa. Selanjutnya dilakukan konsultasi publik atau asistensi bersama perangkat desa dan perwakilan lembaga yang ada di desa terhadap kandungan materi yang dimuat dalam semua dokumen dimaksud (gambar 5). Rekomendasi dan koreksi atas temuan data lapangan yang didapat dari konsultasi publik selanjutnya menjadi rujukan bagi finalisasi dokumen profil desa, monografi desa, desa dalam angka maupun dokumen turunan lainnya.

Proses koreksi draft dokumen dilakukan bersama oleh aparat desa dan peserta KKN PPM dalam kerangka pendampingan pembuatan 
profil desa dan merupakan rangkaian kegiatan yang terprogram dalam serial pelatihan yang telah direncanakan. Proses selanjutnya adalah finalisasi dokumen profil desa, dilakukan dengan melengkapi dokumen dengan memasukkan sampul laporan, prakata dan kemudian dilakukan pencetakan dan penjilidan dokumen.

Proses koreksi draft dokumen bersama oleh aparat desa dan peserta KKN PPM dilakukan dalam kerangka pendampingan pembuatan profil desa dan merupakan rangkaian kegiatan yang terprogram dalam serial pelatihan yang telah direncanakan. Dari proses ini kemudian didapatkan dokumen final profil desa dan monografi desa beserta turunannya yang dilengkapi dengan halaman penunjang antara lain sampul laporan, prakata dan lainnya.
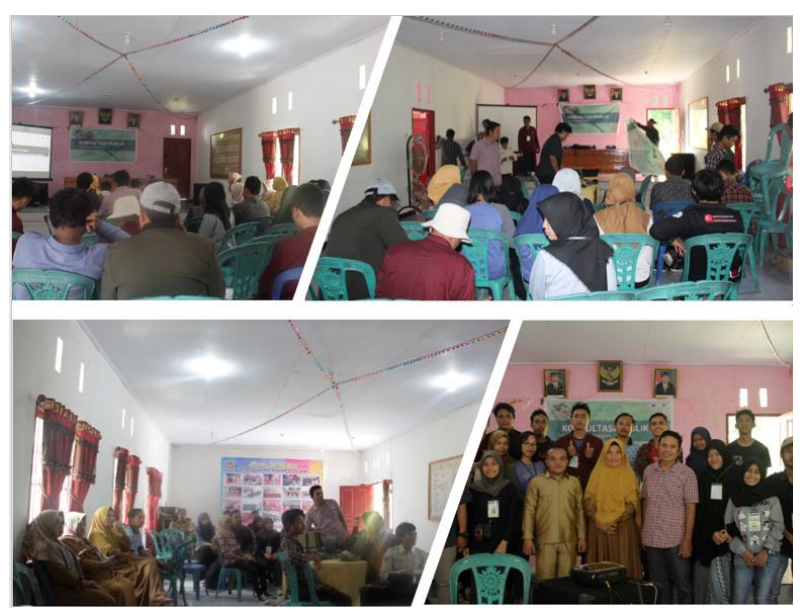

Gambar 5 Konsultasi publik materi profil desa

Dokumen final profil desa dan monografi desa dimaksud selanjutnya dikemas menjadi 5 buah buku yakni

- Buku 1: Profil Desa Huntulohulawa (Data Dasar Keluarga) setebal 36 halaman,

- Buku 2: Profil Desa Huntulohulawa (Potensi Desa) setebal 49 halaman,

- Buku 3: profil desa Huntulohulawa (Tingkat Perkembangan) setebal 65 halaman,

- Buku 4: Monografi desa Huntulohulawa setebal 25 halaman, dan

- Buku 5: Huntulohulawa dalam Angka setebal 50 halaman.

Lebih lanjut, seluruh dokumen ini akan menjadi sajian informasi website desa pada menu publikasi.

\section{Pembuatan Peta}

Sebelum pembuatan peta, dilakukan pelatihan pembuatan peta bagi tim pemetaan yang terdiri atas mahasiswa KKN PPM, Aparat desa dan karang taruna, menggunakan metode pembelajaran orang dewasa yang dikombinasikan dengan metode learning by doing dan metode penerapan ipteks. Materi yang diberikan antara lain pengenalan dan cara mengoperasikan GPS, tracking jalur, digitasi dan layout peta, dilaksanakan dalam bentuk pemberian materi dalam kelas dan praktek lapangan.

Setelah pengambilan data spasial yang dilakukan oleh tim kemudian dilakukan proses digitasi, analisis peta dan layout. Analisis peta dilakukan untuk menghitung luasan penggunaan lahan untuk setiap peruntukan ruang. Proses ini dilakukan bersama mitra eksternal (Japesda, n.d.) dan kelompok studi Mapala Alaska dengan menerapkan metode tutor sebaya selama kurang lebih 1 minggu, dan menghasilkan 3 buah peta tematik yakni peta dasa wisma, peta wilayah administratif (citra), dan peta peruntukan lahan.

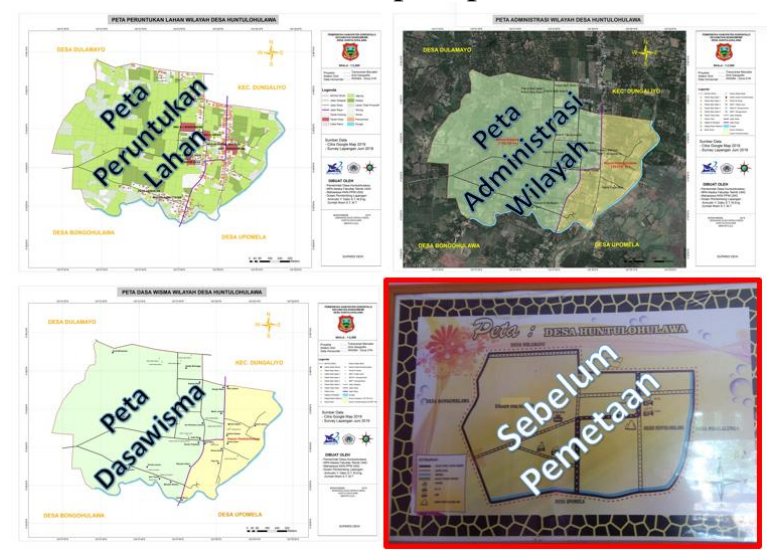

Gambar 6. Peta hasil kegiatan pemetaan

Proses finishing peta menggunakan standar (Badan Informasi dan Geospasial Republik Indonesia, 2016). Lebih lanjut, perhitungan kuantitas, volume dan luas obyek ruang yang ada di desa dituliskan dalam buku perhitungan pemetaan yang merupakan bagian tak terpisahkan dari kegiatan pembuatan peta. Buku ini juga merupakan sajian informasi website desa yang bisa diunduh dengan gratis.

\section{Pembuatan Website}

Website atau sistem informasi desa dibuat menggunakan PHP-MYSQL yang merupakan pengembangan website luaran dari kegiatan penelitian/pengabdian yang telah dilakukan 
sebelumnya (Dako \& Ilham, 2016), (Ilham \& Dako, 2016) (Dako \& Tolago, 2017). Pengembangan yang dilakukan ditujukan untuk memenuhi keinginan user, yakni pemerintah desa Huntulohulawa, berupa modifikasi layout, penambahan beberapa fitur dan fungsi serta optimasi website secara keseluruhan. Setelah melalui pengujian teknis, hasil pengembangan website kemudian ditempatkan pada alamat http://huntulohulawa.desa.id. Penggunaan domain desa.id disesuaikan dengan standar yang dikeluarkan oleh Depkominfo RI untuk sistem informasi desa.

Hasil eksekusi halaman awal dari website desa Huntulohulawa ditunjukkan pada gambar 7.

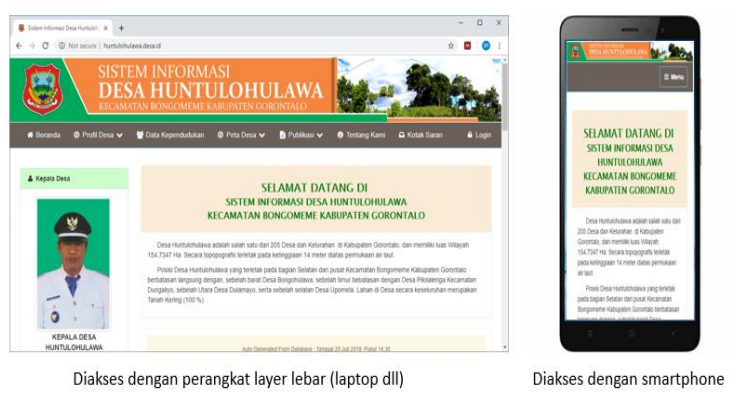

Gambar 7. Cuplikan halaman awal website

Lebih lanjut, pengembangan website dilakukan pada beberapa fitur antara lain

- peningkatan fitur pemilahan data dengan opsi kategori yang lebih beragam pada basis data kependudukan yang terintegrasi dengan website,

- Penambahan menu untuk visualisasi sebaran data kependudukan, basis data dasawisma, lokasi kantor desa dan wilayah administrasi desa berbasis sistem informasi geografis (SIG),

- Fitur layanan administrasi kependudukan untuk menangani permintaan pembuatan surat secara daring oleh warga desa

- Fitur kotak saran/aduan digital dan managemen informasi dalam lingkup desa,

- Pembuatan dan pengarsipan surat keluar terintegrasi dengan basisdata,

- Fitur unduh/download file peta resolusi tinggi dan informasi spasial sebaran penduduk,

- Publikasi infografis desa, profil desa, monografi desa, dan desa Huntulohulawa dalam angka.
- Peraga layar lebar papan informasi digital untuk sajian informasi pengumuman, agenda serta presensi aparat desa,

- Penambahan menu statistik / Fitur grafik interaktif untuk sajian informasi kependudukan berbasis pada data terkini yang tersedia dalam basisdata,

- Galery foto dan video yang terintegrasi dengan akun berbagi pakai video secara daring.

Cuplikan hasil eksekusi beberapa fitur dimaksud disajikan pada gambar 8 .

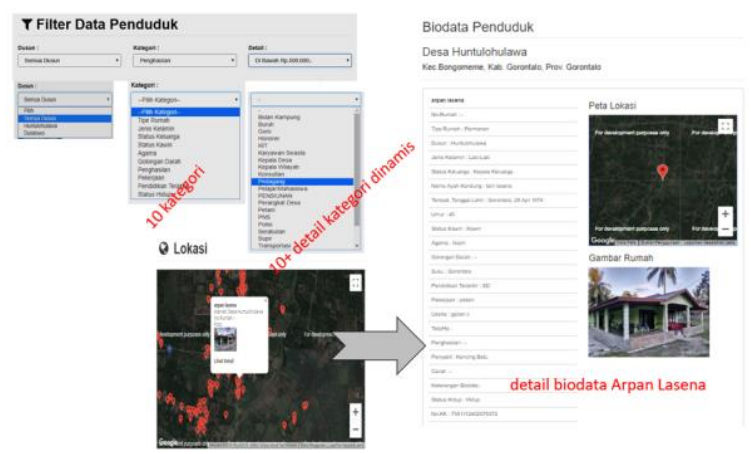

Gambar 8. Cuplikan sajian informasi data penduduk dengan dukungan SIG

Website ini merupakan 'jendela' untuk melihat semua hasil kerja program pengabdian yang telah dilakukan. Website ini dilengkapi pula dengan buku panduan penggunaan website, baik bagi pengguna umum maupun administrator pengelola website desa yang secara khusus dibuat untuk menjadi pegangan bagi aparat desa dalam pengelolaan website desa dan menjadi dukungan materi bagi pembelajaran dan pelatihan pengelolaan sistem informasi (website) desa pada waktu mendatang.

\section{Pelatihan dan Pendampingan}

Kegiatan pelatihan dan pendampingan kelompok sasaran dilakukan secara serial sepanjang pelaksanaan program sesuai dengan tahapan pelaksanaan program, meliputi pelatihan Pelatihan Pemetaan / PRA, Pelatihan Pengolahan dan Analisis Data Profil Desa, Pelatihan Dasar Komputer dan internet, Pelatihan Management Database, Pelatihan Management Website dan Penerapan IPTEKS secara umum. Materi Pelatihan ditekankan pada pengenalan aplikasi khususnya MS Excell, MS Word dengan contoh kasus nyata yang dihadapi, misalnya mengelola data kependudukan, membuat dokumen profil desa, monografi desa 
dan desa dalam angka serta pengelolaan konten website desa.

\section{Pelaksanaan Program Tambahan}

Program tambahan adalah program diluar program inti, dilaksanakan dalam rangka menunjang program pembangunan desa, bersifat mendesak dan memungkinkan ditangani oleh sumberdaya yang ada dalam tim. Program tambahan dimaksud antara lain papan informasi digital dan pembuatan peta tambahan.

Papan informasi digital berupa sebuah peraga informasi berbentuk TV LED berukuran 43" berbasis Raspbery Phi yang dipasang pada loby kantor desa. Sajian informasi yang ada di papan informasi ini dikontrol melalui website desa pada menu pengelolaan papan info digital. Warga desa selanjutnya dapat melihat pengumuman, agenda dan kehadiran aparat desa melalui 'menu papan info' yang ada di website desa, sehingga warga desa yang memiliki kepastian penyelesaian urusan administrasi dengan aparat desa yang memerlukan tatap muka langsung.

Peta tambahan dimaksud adalah peta yang disesuaikan dengan kebutuhan desa, antara lain peta peruntukan lahan detail yang ditujukan untuk mengantisipasi aparat desa dalam perhitungan luasan lahan guna keperluan pengurusan surat tanah/sertifikat prona. Peta lainnya adalah peta pemukiman detail yang memuat luasan rumah yang diproyeksikan untuk pembuatan sistem monitoring pajak bumi dan bangunan. Hasil perhitungan detail peruntukan lahan dan rumah dapat dilihat pada buku perhitungan peta desa Huntulohulawa yang dapat diakses lewat menu publikasi pada website desa.

\section{Launching Website dan Penyerahan Produk KKN PPM}

Website yang telah dibangun dinamai 'tipende' oleh Pemerintah desa Huntulohulawa. Akronim tipende merupakan singkatan dari "teknologi informasi pemerintah desa". Launching website dilaksanakan pada tanggal 6 Agustus 2019, didahului oleh sambutan kepala desa, presentasi DPL dan Bapak Bupati Kabupaten Gorontalo. Acara dihadiri oleh antara lain Camat, kepala dinas PU, wartawan, tenaga kesehatan, seluruh kepala desa beserta aparat desa dan BPD/LPM yang ada di wilayah kecamatan Bongomeme, serta masyarakat desa Huntulohulawa (gambar 9).

Pada kegiatan ini pula, Bupati berkesempatan menguji sistem informasi yang telah dibangun, dan menghimbau kepada seluruh kepala desa yang ada untuk dapat mencontoh inovasi desa dalam bentuk website desa dan kemudian dapat menindaklanjutinya dalam perubahan penganggaran desa pada akhir tahun, atau penganggaran tahun berikutnya.

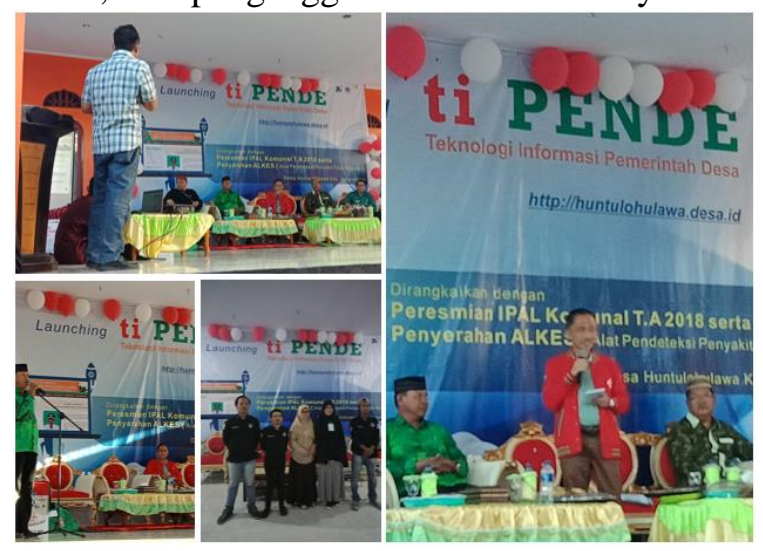

Gambar 9. Launching Website Desa

Selanjutnya, penyerahan produk KKN PPM dilaksanakan di hari yang sama (gambar 10). Produk KKN PPM yang diserahkan adalah seluruh luaran baik cetak maupun digital yang dikemas dalam bentuk buku, CD maupun hak akses terhadap seluruh akun digital yang dibuat.
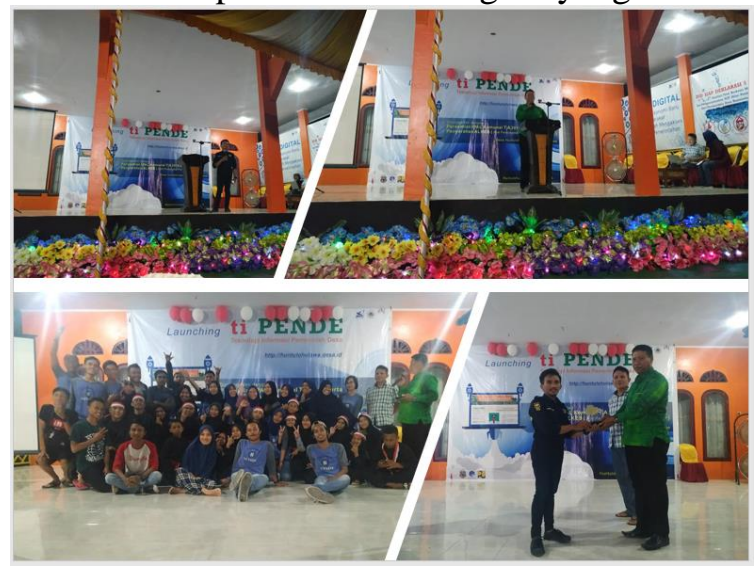

Gambar 10. Penyerahan Produk KKN PPM

Saat tulisan ini dibuat, website desa Huntulohulawa telah beroleh sertifikat Hak atas Kekayaan Intelektual (HKI) dengan judul ciptaan "Sistem Informasi Desa Huntulohulawa Kecamatan Bongomeme Kabupaten Gorontalo", dengan nomor permohonan 
EC00201949089, tanggal 5 Agustus 2019, jenis ciptaan "Program Komputer" dan nomor pencatatan 000149016.

\section{KESIMPULAN}

Program KKN PPM di desa Huntulohulawa kecamatan Bongomeme Kabupaten Gorontalo, telah menghasilkan

- Terselenggaranya kegiatan serial pelatihan dan pendampingan untuk aparat desa Huntulohulawa dalam bentuk pelatihan dasar komputer/internet, managemen database kependudukan dan pengelolaan website desa, serta bimbingan teknis untuk pengolahan dan analisis data profil desa dan pendampingan intensif penyusunan dokumen profil desa, yang selanjutnya telah dapat meningkatkan pengetahuan, keterampilan serta pelayanan publik dari kelompok sasaran

- 3 (tiga) buah cetakan peta tematik terkini Desa Huntulohulawa dengan format standar lengkap dengan acuan koordinat lokasi, 2 buah peta detail dalam bentuk digital dan dilengkapi dengan Buku Perhitungan Peta.

- database kependudukan berbasis MS Excel yang memuat seluruh data terkait profil desa,

- Sistem Informasi Desa berbentuk website desa berbasis sistem informasi geografis yang dapat diakses secara daring pada alamat http://huntulohulawa.desa.id, dilengkapi dengan buku panduan penggunaan website desa, dan memuat keseluruhan hasil produk KKN PPM antara lain 3 buah Buku Profil desa, Buku Monografi Desa dan Buku Desa Huntulohulawa Dalam Angka.

- HKI untuk jenis ciptaan program komputer "Sistem Informasi Desa Huntulohulawa Kecamatan Bongomeme Kabupaten Gorontalo", nomor pencatatan 000149016.

- Papan informasi digital dengan peraga TV LED berukuran 42" terpasang di loby Kantor desa

- Terselenggaranya kegiatan tambahan berupa pembuatan infografis dan administrasi desa, pembuatan media promosi desa, pembenahan kantor desa dan sarana olahraga, kerja bakti/jumat bersih untuk pembersihan lingkungan sekitar dan 'safari jumat' di setiap mesjid yang ada di desa.

\section{UCAPAN TERIMA KASIH}

Ucapan terima kasih disampaikan kepada Direktorat Riset dan Pengabdian Masyarakat, Direktorat Jenderal Penguatan Riset dan Pengembangan Kementrian Riset, Teknologi, dan Pendidikan Tinggi Republik Indonesia, yang telah memberikan alokasi dana untuk pelaksanaan kegitan ini. Terimakasih juga diucapkan kepada Lembaga Penelitian dan Pengabdian Kepada Masyarakat Universitas Negeri Gorontalo, Kepala Desa Huntulohulawa beserta seluruh aparat desa, Karang Taruna, PKK, BPD dan LPM serta seluruh warga desa Huntulohulawa. Selanjutnya ucapan terima kasih juga disampaikan kepada tim pemetaan Alaska, Japesda Gorontalo dan seluruh tim pengabdian kepada masyarakat yang sudah berkontribusi pikiran dan waktu untuk mensukseskan kegiatan ini.

\section{DAFTAR PUSTAKA}

Badan Informasi dan Geospasial Republik Indonesia. Spesifikasi Teknis Penyajian Peta Desa (2016). Diambil dari https://jdih.big.go.id/hukumjdih/3445764

BPS Kabupaten Gorontalo. (2018). Kecamatan Bongomeme Dalam Angka 2018. Gorontalo. Diambil dari https://gorontalokab.bps.go.id/publication/ 2018/09/26/6ed15661b1569c92fbd582bc/ kecamatan-bongomeme-dalam-angka2018.html

Dako, A. Y., \& Ilham, J. (2016). Prototipe Website Untuk Sajian Informasi Profil Desa Binaan Universitas Negeri Gorontalo Sebagai Salah Satu Implementasi Pengembangan Tridharma Perguruan Tinggi. Setrum: Sistem Kendali-TenagaElektronika-Telekomunikasi-Komputer, 3(2), 77-85. Diambil dari http://jurnal.untirta.ac.id/index.php/jis/arti cle/view/508

Dako, A. Y., \& Tolago, A. I. (2017). Laporan Pelaksanaan KKN PPM Desa Bongopini Pengelolaan Berkelanjutan Profil Desa Bongopini Dengan Optimasi Dukungan Manajemen Berbasis Komputer. 
Gorontalo.

Ilham, J., \& Dako, A. Y. (2016). Laporan Pelaksanaan KKN PPM Desa Iloheluma Optimasi Pengelolaan Data Profil Desa Iloheluma Dengan Introduksi Sistem Pengelolaan Berbasis Komputer.

Japesda. (n.d.). JAPESDA | Jaring Advokasi Pengelolaan Sumber Daya Alam. Diambil 13 Agustus 2019, dari http://japesda.org/

Kementrian Dalam Negeri Republik Indonesia, B. P. D. (2018). Data Pokok Desa Huntulohulawa. Diambil 19 Oktober 2018, dari

http://prodeskel.binapemdes.kemendagri.g o.id/dpokok_grid_t01/

Pemerintah Indonesia. Peraturan Menteri Dalam Negeri No. 12 Tahun 2007 Tentang Pedoman Penyusunan dan Pendayagunaan Data Profil Desa dan Kelurahan (2007). Diambil dari http://binapemdes.kemendagri.go.id/produ k_hukum/download/70efdf2ec9b0860797 $95 \mathrm{c} 442636 \mathrm{~b} 55 \mathrm{fb}$

Pemerintah Indonesia. Peraturan Menteri Dalam Negeri No. 13 tahun 2012 tentang Monografi Desa dan Kelurahan, Pub. L. No. 13 (2012). Diambil dari http://binapemdes.kemendagri.go.id/produ khukum/download/14/Permendagri_No. 13_Th_.2012_Ttg_._Monografi_Desa_D an_Kelurahan_.doc 